\title{
A Proposed Model of Trust Factors for E-government Adoption and Civic Engagement
}

\author{
Suha AlAwadhi \\ Kuwait University \\ s.alawadhi@ku.edu.kw
}

\begin{abstract}
This study aims to explore trust factors affecting the use and adoption of e-government services and its impact on civic engagement. The constructs identified in this study are related to theories of technology adoption in addition to trust constructs: trust in government, trust in technology, and trust in egovernment. The study attempts to propose a model and validate it in the context of a developing country. As this study is exploratory in nature, a questionnaire survey is undertaken using a small sample of 137 participants. The findings show the validity and the reliability of the constructs which are positively correlated with each other. The findings of general Linear model analysis propose a model of trust factors that have significant relationships with the adoption of e-government services and leading to civic engagement.
\end{abstract}

\section{Introduction}

During the past decades, public trust in government has been declining due to administrative, political and economic causes, such as administrative corruption, inefficiency and ineffectiveness of government, political scandals, and policy failures. This has had an impact on public participation in governments which has also declined to some extent. Also, citizens have been isolated from community life and their ability to articulate demands for good government that ensures quality of life has noticeably decreased [35]. However, West [51] and Lollar [33] projected that e-government and its use help bring about positive change in citizens' beliefs about government effectiveness and re-build citizens' trust in government. The use of Information and Communication Technology (ICT) in governments has introduced new forms of interaction that could enhance different types of relationships, including a government-public relationship where information is shared and exchanged [34], [50]. Therefore, local, regional, and national governments around the world provide access to ICT solutions to offer effective government information and services, to achieve economic and social development, and to enable social inclusion [9]. E-government projects have introduced several opportunities for online interaction, which subsequently empower citizens at various levels, such as: information accessibility, political participation, influencing government decisions, linking groups to the broader community, and making governments more accountable to their citizens [9]; [7]; [2].

There is a growing body of literature that focuses on egovernment and user engagement [15], [27], [24], that has contributed greatly in developing an understanding of the impact of ICT on civic engagement [30]. Other researchers have indicated that some political behaviours have linked trust and civic engagement [38]; [43] that such linkage is complex and trust is the "magic elixir for civic engagement" [43]. However, the literature has little explanation on the relationships between building trust in e-governments, the adoption and use to e-government and civic engagement. Moreover, to the best of researcher's knowledge, studies on such relationships in developing countries, specifically the Middle East countries, are either nonexistent or insufficient. Therefore, this study uses Kuwait as an example of a developing country in this context and is expected to propose a model for the adoption of e-government services through trust constructs (technology, government, and egovernment), civic engagement and other related factor.

The paper is organized as follows: first, the study background is presented. Next, the academic literature on the adoption of e-government is reviewed. Then, the research model is proposed and the methodology used is described. This is followed by the presentation of the findings. Finally, the discussion and conclusions are presented.

\section{Study background}

Kuwait has adopted e-government since 2000 to improve government's performance and to promote 
efficiency and transparency [4]. A lot of efforts are devoted for the improvement of e-government in Kuwait to present government information and services needed by the public [32]. Although many government organizations and ministries have produced government information and offered services online using ICT tools, such as websites and social media networks, the adoption of such e-government is still limited. This is confirmed by report of Transparency International [42] which ranked Kuwait 55 out of 168 countries around the world in Corruption Perceptions Index for 2015; indicating that the government in Kuwait is not revealing adequate information, practicing transparency appropriately, and or sufficiently including the public.

Several studies have discussed the e-government in Kuwait from different perspectives, such as its adoption [4]; [6]; [5]; however, little is known about trust perceptions of the public with regard to egovernment which lead to civic engagement. This limitation in the literature has commended to conduct this study to minimize the gap by attempting to explore public perceptions towards trust in the adoption of egovernment information and services to achieve civic engagement.

\section{Literature review}

The literature has discussed the important role of web technology use in governments that redefine government-public relationships where trust in government is re-built, citizens become able to express their views and become more engaged with their governments [28]; [31]; [29]. Civic engagement is considered a positive force that enhances social trust, norms, and values [23]. It could be a "bit of everything": political participation, volunteering, community services, and social networks and interpersonal trust to associational involvement [1], [39], [10], [19]. The social capital literature found that civic engagement not only stems from trust but also can lead to greater trust [19]. Putnam confirms [38] the relationship between civic engagement and trust, however it is complex. Also, Brehm and Rahn [12] found a linkage between civic engagement and trust.

Many studies provide evidence that trust is an important factor in the acceptance and adoption of egovernment services [14]. Trust has been defined as "a psychological state comprising the intention to accept vulnerability based upon positive expectations of the intentions or behavior of another" [41, p.395]. Several researchers found that the use of e-government services is correlated with the trust in government; for example: [13]; [36]; [48]; [51]. Other researchers, conversely, found that trust in government is not necessary for using of e-government services; for example: [25].

Scholars have also explored the relationship between citizens' use of e-government services and their trust in technology. A study investigating the relation between trust and e-government [16] found that citizens with higher perceptions of technological and organizational trustworthiness, have higher trust in e-government. Users with positive experience of the technology and satisfactory use of the services are more likely to develop a positive attitude and thus adopt online services than those with a negative experience [45]. Internet business is linked to Internet experience that novice users are less likely to conduct business online than experienced users [22]. Also, security and reliability of e-services are the most important dimensions that, if experienced, will incline customers to report a positive experience of e-services [45]. Similarly, Dutton and Shepherd [18] found that trust in the Internet will shape the future of online services. Such trust is undermined by negative experiences that increase the risk entailed using the Internet, such as computer viruses.

Once citizens' adoption of e-government services is achieved, it will have an impact on their engagement as it is associated with the successful e-government and its sustainability [15], [27]. Gil de Zúñiga et al. [24] found that individuals are more likely to display political behavior and engage in civic life in both online and offline conversations. Several researchers found that civic engagement is significantly related with the participation in the political process of government (e.g., [8]; [21]; [44]). Moreover, the use of available e-government information and services and interaction platforms with government allow direct contact and interaction with governments, thereby promoting transparency, participation, and collaboration [26]; [11]. However, Jaeger and Bertot [26] argued that the use of new technologies might marginalize disadvantaged people that do not have access to the Internet.

To sum up, the review of the literature identifies trust in government and technology as factors significant in the adoption of e-government. Moreover, the use of e-government positively impacts on civic engagement which has a linkage with trust.

\section{Research model}

Extensive literature has discussed the acceptance and adoption of e-government services using adoption theories, such as theory of reasoned action (TRA) [20], technology acceptance model (TAM) [17], theory of planed behavior (TPB) [3], and unified theory of acceptance and use of technology (UTAUT) [46]. Such 
empirical studies have identified numerous factors related to e-government adoption, such as perceived usefulness, perceived ease of use, subjective norms, intention to use and attitude behavior. However, other important factors relating to trust and culture have little been considered with adoption theories, such as [40] and [47]. Thus, based on the literature review, this study will focus on trust as an important factor related to the adoption of e-government. Other factors that enhance trust in e-government services are also considered. The following factors are identified and expected to be significantly correlated with the adoption e-government services and have positive impact on civic engagement:

- Trust in e-government (TEG) is mainly related to trust in technology (TT) and government (TG). This trust leads to higher intentions to use e-government (IU) services.

- Perceived usefulness (PU) of e-government services is also important for enhancing trust in egovernment and increase citizens' intention behavior.

- Once e-government services are adopted and used, this means that citizens become able to interact and engage with government, and thereby achieving civic engagement (CE).

Table 1 presents the constructs used in the study and the related statements which have been modified to reflect the context of the study.

Table1. Research constructs

\begin{tabular}{|c|c|c|}
\hline Constructs & Statements & Sources \\
\hline \multirow{4}{*}{$\begin{array}{l}\text { Trust in } \\
\text { Government } \\
\text { (TG) }\end{array}$} & I trust government agencies. & \multirow{4}{*}{$\begin{array}{l}\text { Colesca } \\
(2009)\end{array}$} \\
\hline & $\begin{array}{l}\text { Government agencies keep my } \\
\text { best interests in mind. }\end{array}$ & \\
\hline & $\begin{array}{l}\text { In my opinion, government } \\
\text { agencies are trustworthy. }\end{array}$ & \\
\hline & $\begin{array}{l}\text { The trust in a governmental } \\
\text { agency increase once with its } \\
\text { reputation }\end{array}$ & \\
\hline \multirow[t]{4}{*}{$\begin{array}{l}\text { Trust in } \\
\text { Technology } \\
\text { (TT) }\end{array}$} & $\begin{array}{l}\text { Technologies supporting the } \\
\text { system (such as enquiring about } \\
\text { traffic violations) are reliable all } \\
\text { the time. }\end{array}$ & \multirow[t]{4}{*}{$\begin{array}{l}\text { Colesca } \\
(2009)\end{array}$} \\
\hline & $\begin{array}{l}\text { Technologies supporting the } \\
\text { system are secure all the time. }\end{array}$ & \\
\hline & $\begin{array}{l}\text { The technology used by } \\
\text { government agencies is } \\
\text { trustworthy. }\end{array}$ & \\
\hline & $\begin{array}{l}\text { Overall, I have confidence in the } \\
\text { technology used by government } \\
\text { agencies to operate the e- } \\
\text { government services. }\end{array}$ & \\
\hline \multirow{3}{*}{$\begin{array}{l}\text { Trust on e- } \\
\text { Government } \\
\text { (TEG) }\end{array}$} & $\begin{array}{l}\text { E-government services are } \\
\text { useful for me. }\end{array}$ & \multirow[t]{3}{*}{$\begin{array}{l}\text { Colesca } \\
(2009)\end{array}$} \\
\hline & $\begin{array}{l}\text { I believe that e-government } \\
\text { services are trustworthy. }\end{array}$ & \\
\hline & $\begin{array}{l}\text { I believe that e-government } \\
\text { services will not act in a way that }\end{array}$ & \\
\hline
\end{tabular}

\begin{tabular}{|c|c|c|}
\hline & harms me. & \\
\hline & I trust e-government services. & \multirow{5}{*}{$\begin{array}{l}\text { Pavlou } \\
\text { (2003) }\end{array}$} \\
\hline \multirow[t]{4}{*}{$\begin{array}{l}\text { Civic } \\
\text { Engagement } \\
\text { (CE) }\end{array}$} & $\begin{array}{l}\text { The use of e-government } \\
\text { information and services makes } \\
\text { me willing to interact with } \\
\text { government officials. }\end{array}$ & \\
\hline & $\begin{array}{l}\text { The use of e-government } \\
\text { information and services enables } \\
\text { me to communicate my ideas to } \\
\text { government }\end{array}$ & \\
\hline & $\begin{array}{l}\text { The use of e-government } \\
\text { information and services makes } \\
\text { it easier for me to attend } \\
\text { government public meeting to } \\
\text { discuss government performance }\end{array}$ & \\
\hline & $\begin{array}{l}\text { The use of e-government } \\
\text { information and services makes } \\
\text { government officials } \\
\text { accountable. }\end{array}$ & \\
\hline \multirow[t]{4}{*}{$\begin{array}{l}\text { Intention to } \\
\text { Use (IU) }\end{array}$} & $\begin{array}{l}\text { I am intending to use e- } \\
\text { government information to } \\
\text { conduct my business with } \\
\text { government. }\end{array}$ & \multirow[t]{4}{*}{$\begin{array}{l}\text { Kalu \& } \\
\text { Remkus } \\
(2010)\end{array}$} \\
\hline & $\begin{array}{l}\text { Most probably that I will continue } \\
\text { to use the e-government } \\
\text { information }\end{array}$ & \\
\hline & $\begin{array}{l}\text { I am planning to continue to use } \\
\text { the e-government services in the } \\
\text { future. }\end{array}$ & \\
\hline & $\begin{array}{l}\text { I will use the e-government } \\
\text { information if it is handy and } \\
\text { available. }\end{array}$ & \\
\hline \multirow{4}{*}{$\begin{array}{l}\text { Perceived } \\
\text { Usefulness } \\
\text { (PU) }\end{array}$} & $\begin{array}{l}\text { Using e-government helps me } \\
\text { greatly in doing my work. }\end{array}$ & \multirow[t]{4}{*}{$\begin{array}{l}\text { Pavlou } \\
\text { (2003) }\end{array}$} \\
\hline & $\begin{array}{l}\text { Using e-government enhance my } \\
\text { performance. }\end{array}$ & \\
\hline & $\begin{array}{l}\text { Using e-government improves } \\
\text { performance quality. }\end{array}$ & \\
\hline & $\begin{array}{l}\text { Using e-government facilitates } \\
\text { knowledge challenges. }\end{array}$ & \\
\hline
\end{tabular}

This exploratory study attempts to validate the proposed model through finding out factors affecting the adoption of e-government services for civic engagement. The following hypotheses are suggested:

H1: There is significant relationship between trust in government and trust in e-government.

H2: There is significant relationship between trust in technology and trust in e-government.

H3a: There is significant relationship between trust in e-government and intention to use.

$H 3 b$ : There is significant relationship between trust in e-government and civic engagement.

H4a: There is significant relationship between perceived usefulness and trust in e-government

$H 4 b$ : There is significant relationship between perceived usefulness and intention to use egovernment services.

H4c: There is significant relationship between perceived usefulness and civic engagement. 


\section{Methodology}

This study is exploratory in nature. It seeks to identify factors that have significant relationships on the intention to use e-government. Also, it examines the interaction of these factors on the intention of use and its impact on civic engagement.

\subsection{Sampling}

The questionnaire was administered to individuals in Kuwait aged 18 years old and above, as they are eligible to use e-government services. Due to the explanatory nature of the current study, the researcher adopted a non-probability, convenience sampling method which targeted a small number of participants. The questionnaire was distributed online among individuals in Kuwait society using email and social media networks and 137 responses were received.

\subsection{Survey instrument}

The study has employed the quantitative datacollection approach using a questionnaire survey method. The survey tool was purposively designed in a clear and straightforward way, using a simple language as it targets various groups in the community with different educational, cultural, and social backgrounds. The questionnaire is divided into two main sections: the first section assembles demographic information of respondents and their internet proficiency; the second section is related to the identified research constructs where respondents should give their opinions using a Likert scale ranging from 1 "strongly disagree" to 5 "strongly agree".

The questionnaire was first designed in English and then translated into Arabic, the spoken language in Kuwait. This gives everyone residing in Kuwait the opportunity to participate in the study. To ensure the validity and reliability of the questionnaire, a panel made up of two faculty members from the Information Studies Department and one statistician revised the survey for any errors or ambiguities. All corrections and changes suggested by the panel were taken into consideration. Moreover, a pilot study was undertaken using 50 participants to evaluate the feasibility of the questionnaire statements. The 50 questionnaire responses were statistically analysed and the suggested changes were made to ensure better clarity of statements.

\section{Results}

In this section, data extracted from questionnaire responses are analyzed using SPSS and the results are reported as follows.

\subsection{Sample demographic characteristics}

The sample was $21.2 \%$ males and $78.8 \%$ females, most respondents $(76.5 \%)$ were aged 30 and above, and $48.2 \%$ had undergraduate degrees. The majority of respondents $(92.7 \%)$ were Kuwaiti nationals and $67.2 \%$ had excellent Internet skills, as shown in Table 2.

Table 2. Demographic characteristics of the research sample

\begin{tabular}{|l|l|c|c|}
\hline \multicolumn{2}{|c|}{ Demographics } & Frequency & Percent \\
\hline \multirow{4}{*}{ Gender } & Male & 29 & $21.2 \%$ \\
\cline { 2 - 4 } & Female & 108 & $78.8 \%$ \\
\hline \multirow{4}{*}{ Age } & $20-25$ & 5 & $5.6 \%$ \\
\cline { 2 - 4 } & $26-30$ & 13 & $14.6 \%$ \\
\cline { 2 - 4 } & $31-35$ & 19 & $21.3 \%$ \\
\cline { 2 - 4 } & $36-40$ & 12 & $13.5 \%$ \\
\cline { 2 - 4 } & $40-$ above & 39 & $43.8 \%$ \\
\hline Education & High School & 11 & $8 \%$ \\
\cline { 2 - 4 } & Diploma & 29 & $21.2 \%$ \\
\cline { 2 - 4 } & University Degree & 66 & $48.2 \%$ \\
\cline { 2 - 4 } & Graduate Degree & 31 & $22.6 \%$ \\
\hline \multirow{4}{*}{ Skills } & Poor & 2 & $1.5 \%$ \\
\cline { 2 - 4 } & Good & 43 & $31.4 \%$ \\
\cline { 2 - 4 } & Excellent & 92 & $67.2 \%$ \\
\hline Nationality & Kuwaiti & 127 & $92.7 \%$ \\
\cline { 2 - 4 } & Non-Kuwaiti & 10 & $7.3 \%$ \\
\hline
\end{tabular}

\subsection{Validity and reliability of constructs}

Since this study is exploratory, exploratory factor analysis was employed for the validity and reliability of the research construct items. Table 3 presents the result of the factor analysis for data reduction. As shown in the Table, the reliabilities of the constructs are high $(\geq 86 \%)$ of the Cronbach alpha coefficient, which proves high internal consistency between instruments for each construct. It is also clear that the explained variance is larger than $78 \%$, which indicates an excellent goodness of fit of the model and valid constructs. Factor loadings, which are greater than $50 \%$, reflect the degree of association between instruments and the construct it measures. Once each construct and its instruments are identified, we express each construct as a weight average. These averages will be used to model the relationship between Civic engagement (CE) as dependent variable, and a set of predictors including: Trust in government (TG), Trust in technology (TT), Trust in e-government (TEG), Intention to use e-government (IU), and Perceived usefulness of e-government (PU). We also consider the 
interaction effects of trust in government, trust in technology, and perceived usefulness in the model.

Table 3. Exploratory factor analysis: Factor loadings, explained variance, reliability coefficient and means of research constructs

\begin{tabular}{|l|c|c|c|c|}
\hline Constructs & $\begin{array}{c}\text { Reliability } \\
\text { Cronbach } \\
\text { alpha } \\
\text { coefficient }\end{array}$ & $\begin{array}{c}\text { Explained } \\
\text { Variance }\end{array}$ & $\begin{array}{c}\text { Factor } \\
\text { loadings }\end{array}$ & Mean \\
\hline TG & $\mathbf{9 1 . 6 \%}$ & $\mathbf{8 5 . 6 4 \%}$ & & $\mathbf{2 . 4 6}$ \\
\hline TG1 & & & .903 & 2.72 \\
\hline TG3 & & & .932 & 2.39 \\
\hline TG4 & & & .940 & 2.27 \\
\hline TT & $\mathbf{9 3 . 3 \%}$ & $\mathbf{8 8 . 2 6 \%}$ & & $\mathbf{3 . 1 9}$ \\
\hline TT2 & & & .941 & 3.27 \\
\hline TT3 & & & .969 & 3.20 \\
\hline TT4 & & & .908 & 3.10 \\
\hline TEG & $\mathbf{8 6 \%}$ & $\mathbf{7 8 . 1 4 \%}$ & & $\mathbf{3 . 5 8}$ \\
\hline TEg1 & & & .889 & 3.82 \\
\hline TEg2 & & & .875 & 3.26 \\
\hline TEg4 & & & .887 & 3.68 \\
\hline CE & $\mathbf{9 4 . 7 \%}$ & $\mathbf{9 0 . 4 6 \%}$ & & $\mathbf{2 . 3 0}$ \\
\hline CE1 & & & .953 & 2.36 \\
\hline CE2 & & & .957 & 2.30 \\
\hline CE3 & & & .943 & 2.25 \\
\hline IU & $\mathbf{9 5 . 4 \%}$ & $\mathbf{9 1 . 6 \%}$ & & $\mathbf{3 . 6 4}$ \\
\hline IU1 & & & .940 & 3.58 \\
\hline IU2 & & & .966 & 3.64 \\
\hline IU3 & & & .965 & 3.70 \\
\hline PU & $\mathbf{9 1 . 5 \%}$ & $\mathbf{8 5 . 4 3 \%}$ & & $\mathbf{3 . 1 7}$ \\
\hline PU1 & & & .893 & 3.09 \\
\hline PU3 & & & .936 & 3.26 \\
\hline PU4 & & & .942 & 3.17 \\
\hline
\end{tabular}

\subsection{Research construct correlations}

The correlation is a measure of association between two variables. It shows by its magnitude the strength of the relationship, whether it is strong, weak, or no association. In addition, its sign indicates the direction of the relationship, whether it is positive or negative, where $r=-1 \leq-\leq 1$. As shown in the Table 4, trust in government has strong positive and significant correlation with trust in technology $(r=0.699 . p-$ value, 0.000$)$, strong positive and significant correlation with trust in e-government $(r=0.560, p-$ value $=0.000)$, weak positive but significant correlation with civic engagement $\left(r=0.388_{s} p-\right.$ value $\left.=0.000\right)$, strong positive and significant correlation with intention to use egovernment services $(r=0.522, p-$ value $=0.000)$ x and finally weak positive but significant correlation with usefulness $(r=0.456, p-$ value $=0.000)$. Trust in technology has strong positive and significant correlation with trust in e-government $(r=0.788, p-$ value $=0.000)$ s weak positive and significant correlation with civic engagement $(r=0.388, p-$ value $=0.000)$. strong positive and significant correlation with intention to use egovernment services $(r=0.667, p-$ value $=0.000)$, and strong positive and significant correlation with usefulness $(r=0.634, p-$ value $=0.000)$. Trust in e-government has weak positive but significant correlation with civic engagement $(r=0.425, p-\text { value }=0.000)_{s}$ strong positive and significant correlation with intention to use egovernment services $(r=0.801, p-$ value $=0.000)$, and also a strong positive and significant correlation with usefulness $(r=0.734, p-$ value $=0.000)$. Civic engagement has weak positive and significant correlation with the intention to use egovernment $(r=0.423, p$-value $=0.000)$, and strong positive and significant correlation with usefulness $(r=0.509 . p-$ value $=0.000)$. Finally, the intention to use e-government has strong positive and significant correlation with perceived usefulness of using e-government $(r=0.710, p-$ value $=0.000)$.

Table 4. Correlation between research constructs

\begin{tabular}{|l|l|c|c|c|c|c|}
\hline Constructs & Statistics & TG & TT & TEG & SI & IU \\
\hline TG & $\begin{array}{l}\text { Pearson } \\
\text { Correlation }\end{array}$ & 1 & & & & \\
\hline TT & $\begin{array}{l}\text { Pearson } \\
\text { Correlation }\end{array}$ & $.699^{* *}$ & 1 & & & \\
\hline TEG & $\begin{array}{l}\text { Pearson } \\
\text { Correlation }\end{array}$ & $.560^{* *}$ & $.788^{* *}$ & 1 & & \\
\hline CE & $\begin{array}{l}\text { Pearson } \\
\text { Correlation }\end{array}$ & $.388^{* *}$ & $.388^{* *}$ & $.425^{* *}$ & 1 & \\
\hline IU & $\begin{array}{l}\text { Pearson } \\
\text { Correlation }\end{array}$ & $.522^{* *}$ & $.667^{* *}$ & $.801^{* *}$ & $.423^{* *}$ & 1 \\
\hline PU & $\begin{array}{l}\text { Pearson } \\
\text { Correlation }\end{array}$ & $.456^{* *}$ & $.634^{* *}$ & $.734^{* *}$ & $.509^{* *}$ & $.710^{* *}$ \\
\hline
\end{tabular}

Note: ${ }^{* *} p<0.001$

The study also investigated the effects of demographic characteristics on research constructs. Several nonparametric tests were run against gender, age group, education, Internet skills, and nationality; however, no significant relationships were found between demographics and research constructs. This could be due to the small number of the sample and significant relationships could be found when a larger sample is used in future research.

\subsection{Building research model}

The General Linear Model (GLM) is a univariate procedure, which provides regression analysis and 
analysis of variance for one dependent variable by one or more variables, was also conducted in this exploratory study. This procedure can test the effects of variables on a single dependent variable and can investigate interactions between variables as well as the effects of individual variables, some of which may be random. We tested the effect of trust in government, trust in technology and, perceived usefulness, and their interactions on trust in e-government. Table 5 provides the measures of goodness of fit of the model using stepwise regression, and the factors standardized scores (obtained from factor analysis) to eliminate the possibility of multicollinearity between constructs. As shown in Table 5 the model is adequate ( $p$-value $=$ $0.000)$, and the coefficient of determination is $72.3 \%$.

Table 5. Analysis of variance test. Dependent variable: Trust in E-government

\begin{tabular}{|l|c|c|c|c|c|}
\hline \multicolumn{1}{|c|}{ Model } & $\begin{array}{c}\text { Sum of } \\
\text { Squares }\end{array}$ & df. & $\begin{array}{c}\text { Mean } \\
\text { Square }\end{array}$ & F-value & $\begin{array}{c}\text { P- } \\
\text { value }\end{array}$ \\
\hline Regression & 98.322 & 3 & 32.774 & 115.689 & $.000^{d}$ \\
\hline Residual & 37.678 & 133 & .283 & & \\
\hline Total & 136.000 & 136 & & & \\
\hline
\end{tabular}

The results in Table 6 show that the only variables having direct effect on trust in e-government are trust in technology, having $53.7 \%$ direct positive and significant effect $(p$-value $=0.000)$, perceived usefulness with $37.6 \%$ direct positive and significant effect $(p$-value $=0.000)$, and their interaction effect which has a negative $(-10.7 \%)$ significant effect $(p$ value $=0.22$ ) on trust in e-government. It is also evident that no indication of multicollinearity problems between variables, the variance inflation factor is $(\mathrm{VIF}<2)$.

The direct effects of trust in government, trust in technology, perceived usefulness and their interactions, trust in e-government, on intention to use egovernment are also investigated. The results of the analysis of variance test (ANOVA) presented in Table 7 indicate that the model is adequate $(p$-value $=0.000)$ with coefficient of determination $R^{2}=67.5 \%$.
Table 7. Analysis of variance test. Dependent variable: Intention to Use

\begin{tabular}{|l|c|c|c|c|c|}
\hline \multicolumn{1}{|c|}{ Model } & $\begin{array}{c}\text { Sum of } \\
\text { Squares }\end{array}$ & df. & $\begin{array}{c}\text { Mean } \\
\text { Square }\end{array}$ & F-value & $\begin{array}{c}\text { P- } \\
\text { value }\end{array}$ \\
\hline Regression & 91.827 & 3 & 45.913 & 139.278 & $.000^{d}$ \\
\hline Residual & 44.173 & 134 & .330 & & \\
\hline Total & 136.000 & 136 & & & \\
\hline
\end{tabular}

Table 8 reports that amongst all variables entered the in the model, only trust in government and perceived usefulness have effect on intention, $60.7 \%$ $(p$-value $=0.000) \quad$ and $26.7 \% \quad(p$-value $=0.000)$ respectively. Other variables deemed insignificant. It is obvious that no multicollinearity exists between variables, since the variance inflation factor (VIF< 2.5).

Direct effects of trust in government, trust in technology, usefulness and their interactions, the trust in e-government, the intention to use e-government on civic engagement are also tested. The results of the analysis of variance test (ANOVA) presented in Table 9 illustrate that the model is adequate $(p$-value $=0.000)$. In addition, the model provided the coefficient of determination $R^{2}=29 \%$. No indication of presence of multicollinearity between variables, the variance inflation factor (VIF < 2).

Table 9. Analysis of variance test. Dependent Variable: Civic Engagement

\begin{tabular}{|l|c|c|c|c|c|}
\hline \multicolumn{1}{|c|}{ Model } & $\begin{array}{c}\text { Sum of } \\
\text { Squares }\end{array}$ & df. & $\begin{array}{c}\text { Mean } \\
\text { Square }\end{array}$ & F-value & $\begin{array}{c}\text { P- } \\
\text { value }\end{array}$ \\
\hline Regression & 39.432 & 3 & 19.716 & 27.358 & $.000^{d}$ \\
\hline Residual & 96.568 & 134 & .721 & & \\
\hline Total & 136.000 & 136 & & & \\
\hline
\end{tabular}

As shown in Table 10, only two variables have direct effects on civic engagement. The perceived usefulness has $41.8 \%$ ( $p$-value $=0.000$ ) effect on civic engagement, and trust in e-government has $19.8 \%(p-$ value $=0.017$ ) effect on civic engagement.

Table 6. The Coefficients: Dependent Variable: Trust in E-government

\begin{tabular}{|l|c|c|c|c|c|c|c|}
\hline \multirow{2}{*}{ Model } & \multicolumn{2}{|c|}{$\begin{array}{c}\text { Unstandardized } \\
\text { Coefficients }\end{array}$} & $\begin{array}{c}\text { Standardized } \\
\text { Coefficients }\end{array}$ & & \multicolumn{2}{c|}{ Collinearity Statistics } \\
\cline { 2 - 7 } \cline { 5 - 8 } & $\mathrm{B}$ & Std. Error & Beta & $\mathrm{t}$ & Sig. & Tolerance & VIF \\
\hline (Constant) & .060 & .052 & & 1.139 & .257 & & \\
\hline Trust in Technology (TT) & .537 & .059 & .537 & 9.079 & .000 & .596 & 1.677 \\
\hline Perceived usefulness (PU) & .376 & .060 & .376 & 6.318 & .000 & .588 & 1.700 \\
\hline TT X PU & -.094 & .041 & -.107 & -2.313 & .022 & .974 & 1.027 \\
\hline
\end{tabular}


Table 8. The Coefficients: Dependent Variable: Intention to Use

\begin{tabular}{|l|c|c|c|c|c|c|c|}
\hline \multirow{2}{*}{ Model } & \multicolumn{2}{|c|}{$\begin{array}{c}\text { Unstandardized } \\
\text { Coefficients }\end{array}$} & $\begin{array}{c}\text { Standardized } \\
\text { Coefficients }\end{array}$ & \multirow{2}{*}{} & & \multicolumn{2}{|c|}{ Collinearity Statistics } \\
\cline { 2 - 6 } \cline { 6 - 8 } & $\mathrm{B}$ & Std. Error & Beta & $\mathrm{t}$ & Sig. & Tolerance & VIF \\
\hline Perceived Usefulness & .607 & .073 & .607 & 8.374 & .000 & .461 & 2.169 \\
\hline Trust in e-government & .265 & .073 & .265 & 3.656 & .000 & .461 & 2.169 \\
\hline
\end{tabular}

Table 10. The Coefficients: Dependent Variable: Civic Engagement

\begin{tabular}{|l|c|c|c|c|c|c|c|}
\hline \multirow{2}{*}{ Model } & \multicolumn{2}{|c|}{$\begin{array}{c}\text { Unstandardized } \\
\text { Coefficients }\end{array}$} & $\begin{array}{c}\text { Standardized } \\
\text { Coefficients }\end{array}$ & \multirow{2}{*}{} & & \multicolumn{2}{|c|}{ Collinearity Statistics } \\
\cline { 2 - 5 } \cline { 7 - 9 } & $\mathrm{B}$ & Std. Error & Beta & $\mathrm{t}$ & Sig. & Tolerance & VIF \\
\hline (Constant) & 1.88 & .073 & & .000 & 1.000 & & \\
\hline Perceived Usefulness & .418 & .082 & .418 & 5.110 & .000 & .791 & 1.265 \\
\hline Trust in e-government & .198 & .082 & .198 & 2.418 & .017 & .791 & 1.265 \\
\hline
\end{tabular}

Figure 1 shows the proposed model and the factors that have significant relationships with the adoption egovernment services for civic engagement. The model indicates that trust in technology and perceived usefulness as well as their interactions have significant relationships with trust in e-government, supporting $\mathrm{H} 2$ and $\mathrm{H} 4 \mathrm{a}$; On the other hand, trust in government did not show any relationship, rejecting $H 1$. Further, trust in e-government has significant relationships with the intention to use e-government services and civic engagement, confirming $H 3 a$ and $H 3 b$. Interestingly, perceived usefulness has shown significant relationships with intention to use e-government services and civic engagement, asserting $\mathrm{H} 4 \mathrm{~b}$, and $\mathrm{H} 4 \mathrm{c}$.

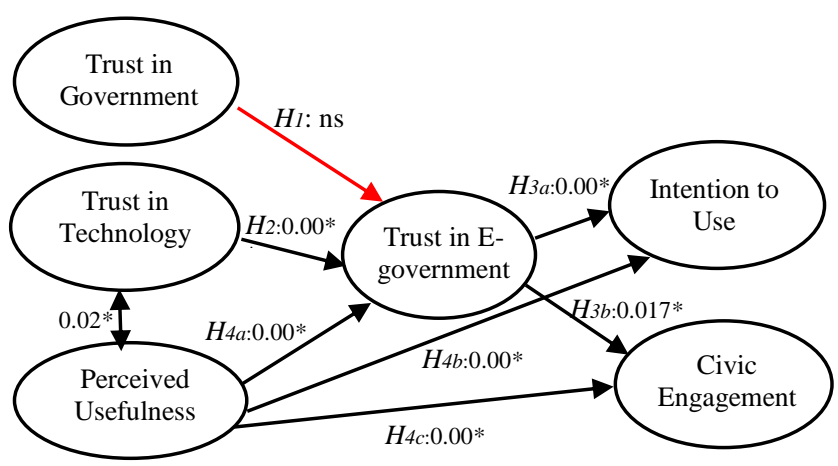

Notes: $* \mathrm{p}<0.05$; ns: not significant

Figure 1. Proposed research model

\section{Discussion and conclusions}

The adoption of e-government services in different countries has been explored by many researchers. Although various studies identified factors that are critical in the acceptance and the adoption of the services, such as perceived usefulness, subjective norms, and attitude behavior; only few studies focused on trust in technology, trust in government, and trust in e-government as factors important for the up-take of online services for civic engagement. Therefore, this exploratory study is expected add to the adoption literature and explore how trust is associated with the adoption of e-government services and how this association, if found, assists in the achievement of civic engagement. Such relationships are explored through constructs identified from the literature and using a questionnaire that targeted adult individuals in the Kuwaiti society. Moreover, this study attempts to propose a model of trust factors and their relationship with the adoption and use of e-government services for civic engagement.

The results of exploratory factor analysis of the identified constructs indicate that research constructs are reliable with higher than $86 \%$ of the Cronbach alpha coefficient, suggesting high internal consistency between statements for each construct. The results also report excellent goodness of fit of research model and that constructs are valid (explained variance larger than $78 \%$ ). The mean average of research constructs higher than 3.17 indicate that respondents have positive perceptions of trust in technology, trust in egovernment, intention to use e-government services 
and its usefulness. As these constructs correlate with the technology, positive perceptions could be attributed to the fact that the majority of respondents have excellent Internet skills and they are familiar with technology use and could conduct many transactions online. The negative perceptions the respondents have towards trust in government and civic engagement with mean averages 2.46 and 2.30 , respectively, confirm the decline in government trust [35] and Kuwait government is not revealing adequate information to the public and not sufficiently engaging the public in the political process [42]. The findings also show significant positive correlations between all research constructs, stressing the direct relationship between trust in technology, in government and in egovernment, usefulness, intention to use e-government, and civic engagement which are significant in the adoption and use of e-government services.

Interestingly, the study attempts to propose a framework and model the adoption of e-government services by testing data using GLM procedure, which provides regression analysis and analysis of variance for one dependent variable by one or more variables. The results demonstrate that trust in e-government is dependent on trust in technology and perceived usefulness, suggesting the respondent might have considered e-government services as any business transaction which can be conducted if they trust the technology and if such transactions are user-friendly and useful to them. These results are in line with many studies, for example [45], [16]. On the other hand, the interaction between trust in technology and perceived usefulness has a significant but negative effect on trust in e-government, suggesting that higher levels of perceived usefulness do not require high trust in technology.

Furthermore, only trust in government and perceived usefulness have significant relationships with respondents' intention to use e-government services. These results indicate that public intentions to deal with government is associated with their trust in government organizations and how their views are taken into consideration by government officials. Also, their intention for using e-government services can be affected by usefulness of service usage as respondents found online services helpful to them that enhance their performance and facilitate government knowledge and information challenges. Additionally, the results illustrate that usefulness of e-government services and trust in e-government have direct and positive effect on civic engagement. This advocates that e-government projects implemented in various countries are expected to offer various tools of interactions with citizens and enhance government-public relationship by sharing and exchanging information, thereby, re-building citizens' trust and achieving civic engagement. These results are in line with [12], [19], [33], [34], [38], [50] [51].

This study is a call for government officials to devote efforts to re-build trust with the public and consider trust constructs as important factors associated with the acceptance, adoption and use of egovernment services. This can be done through improving e-government services and making them useful, beneficial, easy to use to save public's time and effort. Also, e-government programs around the world are expected to share and exchange government information enabling interaction with the public and offer them the tools through which they become able to express their views and specific needs and become part of the political process. This will positively impact citizens' trust in government and consequently achieve civic engagement.

Since this study is exploratory in nature and conducted to validate the proposed model by using a sample limited to a small number of individuals in Kuwait, the results could not be generalized to all individuals in the society. The proposed model, which found to be accepted and adequate, is expected to be conducted to a larger sample size so that generalizability can be applicable to the whole society and also to other countries that share similar circumstances, such as gulf countries. Therefore, further research is required to investigate effectiveness of research constructs on the adoption and use of egovernment services.

\section{References}

[1] R. P. Adler and J. Goggin. "What Do We Mean By "Civic Engagement"?" Journal of Transformative Education, 3, (3), 2005, 236-253.

[2] H. Adnan and S. Mavi. "Bridging social capital on Facebook as a platform: A case study of Malaysian college students.” Asian Social Science, 11, (15), 2015, $1-9$.

[3] I. Ajzen. "The theory of planned behaviour", Organizational Behavior and Human Decision Processes (50:2), 1991, pp.179-211.

[4] S. AlAwadhi and A. Morris. Factors influencing the adoption of e-government services. Journal of Software: "Special Issue on Systems, Science and Applications", 4, (6), 2009, 584-590.

[5] H. Alenezi, A. Tarhini, R. Masa'deh, A. Alalwan, and N. Al-Qirim. "Factors Affecting the Adoption of eGovernment in Kuwait: A Qualitative Study". The Electronic Journal of e-Government, 15, (2), 2017, 84102.

[6] R. M. Alotaibi, M. Ramachandran, A. L. and A. Hosseinian-Far Kor. 'Factors Affecting Citizens' use of 
Social Media to Communicate with the Government: A Proposed Model". The Electronic Journal of eGovernment, 14, (1), 2016, 60-72.

[7] Y. Amichai-Hamburger, K. McKenna and S. Tal. "Eempowerment: Empowerment by the Internet." Computers in Human Behaviour, 24, (5), 2008, 17761789.

[8] R. Andrews. "Civic engagement, ethnic heterogeneity, and social capital in urban areas: Evidence from England." Urban Affairs Review, 44, (3), 2009, 428440.

[9] M. Asgarkhani. "The reality of social inclusion through digital government." Journal of Technology in Human Services, 25, (1), 2007, 127-146.

[10] B. Berger." Political Theory, Political Science, and the End of Civic Engagement". Perspectives on Politics, 7, (2), 2009, 335-350.

[11] E. Bonsón, L. Torres, Lourdes, S. Royo and F. Flores. "Local e-government 2.0: Social media and corporate transparency in municipalities." Government Information Quarterly, 29, (2), 2012, 123-132.

[12] J. Brehm and W. Rahn. "Individual level evidence for the causes and consequences of social capital". American Journal of Political Science, 41, 1997, 8811023.

[13] L. Carter and F. Belanger. "The utilization of egovernment services: citizen trust, innovation and acceptance factors" Information Systems Journal, (15:1), 2005, pp.5-25.

[14] L. Carter and V. Weerakkody. E-government adoption: a cultural comparison. Inform Syst Front, 10,2008,473482

[15] C. Chan and S. Pan. "User engagement in egovernment systems implementation: A comparative case study of two Singaporean e-government initiatives." Journal of Strategic Information Systems, 17, (2), 2008, 124-139.

[16] S. E. Colesca. "Understanding Trust in e-Government". Engineering Economics (3), 2009, 7-15.

[17] F. Davis "Perceived usefulness, perceived ease of use, and user acceptance of information technology" MIS Quarterly, (13:3), 1989, pp.319-339.

[18] W.H. Dutton and A. Shepherd. "Trust in the Internet as an experience technology". Information, Communication \& Society, 9 (4), 2006, 433-451.

[19] J. Ekman and E. Amna. "Political participation and civic engagement: towards a new typology". Human Affairs, 22, (3), 2012, 283-300.

[20] M. Fishbein. and I. Ajzen. Belief, attitude, intention and behaviour: an introduction to theory and research, Addison Wesley, Reading, MA, 1975.

[21] R. Freeman and P. Loo. "Web 2.0 and E-government at the Municipal Level". In: 5th International Conference on e-Government, 19-20 October, 2009, Boston, MA.

[22] J.F. George. "Influences on the intent to make Internet purchases". Internet Research: Electronic Networking Applications and Policy,12 (2), 2002, 165-180.

[23] B. Geys and Z. Murdoch. "Measuring the 'bridging' versus 'bonding' nature of social networks: A proposal for integrating existing measures." Sociology, 44, (3), 2010, 523-540.
[24] H. Gil de Zúñiga, N. Jung and S. Valenzuela. "Social media use for news and individuals' social capital, civic engagement and political participation." Journal of Computer-Mediated Communication, 17, (3), 2012, 319-336.

[25] S. Horsburgh, S. Goldfinch and R. Gauld. "Is Public Trust in Government Associated with Trust in EGovernment?" Social Science Computer Review, 29, (2), 2011, 232-241.

[26] P. Jaeger and J. Bertot. "Transparency and technological change: Ensuring equal and sustained public access to government information." Government Information Quarterly, 27, (4), 2010, 371-376.

[27] J. Jiang, G. Klein, and H. Chen. "The effects of user partnering and user non-support on project performance." Journal of the Association for Information Systems, 7, (2), 2006, 68-89.

[28] M. Johannessen. "Social Capital and the Networked Public Sphere: Implications for Political Social Media Sites." In: Proceedings of the Hawaii International Conference on System Sciences (HICSS-45), Maui, Hawaii, U.S, 2012.

[29] J. Juris. Networked social movements: global movements for global justice. In: The Network Society: A Cross-Cultural Perspective, Manuel Castells, ed. London: Edward Elgar, 2004.

[30] K. Kalu and B. Remkus. "The evolution of social capital and civic engagement between non-profit networks and country samples: A social constructivist approach." The Social Science Computer Review, 28, (1), 2010, 135-150.

[31] S. Kang and S. Gearhart. "E-government and civic engagement: How is citizens' use of city web sites related with civic involvement and political behaviors?" Journal of Broadcasting \& Electronic Media, 54, (3), 2010, 443-462.

[32] Kuwait Government Online. https://www.e .gov.kw 2017.

[33] X. Lollar. “Assessing China's e-government: information, service, transparency and citizen outreach of government websites". Journal of Contemporary China, 15 (46), 2006, 31-41.

[34] L. Mandarano, M. Meenar and C. Steins. "Building social capital in the digital age of civic engagement." Journal of Planning Literature, 25, (2), 2010, 123-135.

[35] M.J. Moon. "The evolution of e-government among municipalities: rhetoric or reality?" Public Administration Review, 62 (4), 2002, 424-433.

[36] M. Parent, C. A. Vandebeek and A.C. Gemino. "Building citizen trust through e-government". In Proceedings of the 37th Annual Hawaii International Conference on System Sciences, 2004.

[37] P.A. Pavlou. "Consumer Acceptance of Electronic Commerce: Integrating Trust and Risk with the Technology Acceptance Model". International Journal of Electronic Commerce, 7 (3), 2003, 69-103.

[38] R. D. Putnam. Bowling alone. New York: Simon and Schuster, 2000. 
[39] R. D. Putnam, R. Leonardi and R. Nanetti. Making Democracy Work. Civic Traditions in Modern Italy. Princeton: Princeton University Press. 1993.

[40] H. M. B. P. Ranaweera. "Perspective of trust towards e-government initiatives in Sri Lanka". SpringerPlus, 5(22). 2016.

[41] D. Rousseau, S. Sitkin, R. Burt, and C. Camerer. "Not so different after all: a cross discipline view of trust". Academy of Management Review 23 (3), 1998, 393 404.

[42] Transparency International, http://www.transparency.org/

[43] E.M. Uslaner and M. Brown. "Inequality, trust, and civic engagement". American Politics Research. 33, (6) 2005, 868-894.

[44] S. Valenzuela, N. Park and K. Kee. "Is there social capital in a social network site? Facebook use and college students' life satisfaction, trust, and participation." Journal of Computer-Mediated Communication, 14, (4), 2009, 875-901

[45] A.C.R. Van Riel, J. Semeijn and W. Janssen. "E-service quality expectations: a case study". Total Quality Management, 14 (4), 2003, 437-450.

[46] V. Venkatesh, M. Morris, G. Davis and F. Davis. "User acceptance of information technology: toward a unified view” MIS Quarterly, (27:3), 2003, pp.425-478.

[47] A.Voutinioti. "Determinants of user adoption of egovernment services in Greece and the role of citizen service centres". Procedia Technology 8, 6th International conference on ICT in agriculture, food and environment, 2013, 238-244

[48] M. Warschauer. "Technology and social inclusion: Rethinking the digital divide." Education for Information, 21, (2, 3), 2003, 195-196.

[49] E. W. Welch and C. C. Hinnant. Internet use, transparency, and interactivity effects on trust in egovernment. 36th Hawaii International Conference on System Sciences, 2003.

[50] B. Wellman, H. Anabel J. Witte and K. Hampton. "Does the internet increase, decrease, or supplement social capital? Social networks, participation, and community commitment." American Behavioral Scientist, 45, (3), 2001.

[51] D. West. "E-government and the transformation of service delivery and citizen attitudes." Public Administration Review, 64, 2004, 15-27. 